\title{
Cultural Communication and Cultural Transmission: The Case of Popular Tradition in Corsica
}

\author{
Margarita Kefalaki ${ }^{1}$ \\ Eirini Daskalaki \\ Fotini Diamantidaki ${ }^{3}$
}

\begin{abstract}
Culture is produced, shaped and transmitted through intergroup relations provoked by communication. In this paper it is examined the cultural communication alternations in a popular culture. More particularly, taking the case of dance practice in Corsica, it is described the actual dance situation. The purpose of this paper is to propose communication modules to avoid a possible cultural loss. This qualitative study is based on field research, in-depth interviews and observation. The lead researcher had the opportunity to observe the dance condition in Corsica, during the five (5) years that she lived on this island (2003 - 2007), exchanging and communicating with dance associations and other cultural organisations.

Dance activity in Corsica today is considered a limited practice, as dance associations are the only places where it is experienced. This study identified an intergroup relation difficulty among the different dance associations. Some of the actions proposed in this study in order to improve communication and consequently improve the actual situation of insufficient dance transmission and practice is to follow common rules, propose a specific agenda with dance events, invite younger people to dance, achieve members' identification by creating intercultural groups, mixing the teams with regard to nationality and promote cultural education and research.
\end{abstract}

Keywords: cultural communication, intergroup relations, exchange, preservation, dance tradition, intangible cultural heritage

\section{Introduction}

Culture is a notoriously difficult term to define. In 1952, the American anthropologists, Kroeber and Kluckhohn, critically reviewed concepts and definitions of culture, and compiled a list of 164 different definitions. Apte (1994; 2001), writing in the volume Encyclopedia of Language and Linguistics summarize the problem as follows: Despite a century of efforts to define culture adequately there was in the early 1990s no agreement among anthropologists regarding its nature (Spencer-Oatey, 2000:3). Therefore, for the purposes of this study culture is considered according to following three aspects: i) conservation: culture as an asset, tangible or intangible and a carrier of local identity; ii) production: culture as a commodity which needs to be re-produced not only to reconstitute cultural capital but also as a source of economic development insofar it is embedded in production processes; and iii) valorisation: culture as a set of norms

\footnotetext{
${ }^{1}$ Professor, Hellenic Open University of Greece, email: mke@ coming.gr

${ }^{2}$ Academic Director \& Head of Research Centre at ACC Akademia College, Cyprus, email:daskalaki.eir@gmail.com

3 Lecturer, UCL Institute of Education, University of London, UK, email:F.Diamantidaki@ ucl.ac.uk
} 
and capacities which enrich communities, used as a bridge builder and carrier of good relations for social and economic exchange (Bekemans, 2013:171).

Within this framework, it will be discussed how culture can be understood and what forms it can take in everyday life. Firstly, culture allows and facilitates communication either verbal or non-verbal. Apart from words people use many ways to communicate nonverbally, such as: music, sounds, dressing, symbols, tradition and so on. Members who belong to the same cultural group can be understood and communicate easier because they share the same cultural characteristics. Secondly, culture becomes a means of belonging simply because members of the same cultural group become automatically members of a broader group i.e. country, religion, so it forms their social identity. Our social identity influences how we live within diverse cultural contexts and relate to a range of social groups and institutions (Jenkins, 1996). Thirdly, culture becomes a vehicle for self-representation in the sense that individuals can act as ambassadors of their own culture by safeguarding and transmitting their linguistic, artistic and cultural heritage. Culture is a living organism that can only develop and expand through exchange and communication.

Nevertheless, exchanging and preserving a culture can be regarded as conflicting goals. Preservation is the procedure of keeping away from outside impacts, while exchanging and communicating is almost the opposite. This conflict can be considered a feature of many modern societies that 'fight' between keeping an inherent culture before adapting to a new reality, via the means of communication.

This study examines the actual activity of dance associations in Corsica, with the dance in Corsica being a rather neglected practice. The study looks into the traditional dance practice and dance transmission in Corsica and proposes actions that could promote this practice further. What could potentially prevent cultural loss and what can add to the cultural preservation? With these research questions in mind, it is highlighted in what ways a culture can retain its difference which will enable its people to preserve and promote their intangible heritage. Concepts of 'united culture' are explored with the possible effects and actions required by the community to preserve cultural differences, promote dance practice, and prevent a possible cultural loss.

\section{The cultural situation in Corsica}

French occupation in 1969 brought an air of change, as far as the cultural and generally the social organization of the island was concerned. A new language, new customs, new habits and generally a different social and administrative organization, that was in some way imposed, had a main impact on Corsica's society. This is said to be the reason for the appearance of the island's "cultural problem", which for many specialists constitutes an obstacle for its development. Jacques Thiers, professor and director of Pascal Paoli University's cultural centre at the time of the study, explained that the French occupation brought along cultural changes that the inhabitants were not ready to accept and follow, as a necessary plan of integration hadn't been proposed on time (Thiers, 1979:6).

The region of Corsica is divided into two (2) departments, five (5) districts, fifty-two (52) townships and three hundred sixty (360) municipalities. Inhabitants were estimated at two hundred ninety-four thousands and one hundred and eighteen (294,118) in the 2006 census (Carte de France, 2019). Corsica has its own character, identity and cultural elements. The efforts to conserve the island's historical character, led to the 
appearance of the Riacquistu movement in the 1970s. A self-described cultural militants group that for over 35 years led the movement for cultural reacquisition of the island. Militants have fought to re-appropriate and valorise the vrai (true) Corsican tradition, identity and language (Davis, 2011). The impact of this militant group meant that people used music and more particularly polyphony singing, as the only way to express the island's particular character. It was an effort to preserve the inhabitants' intangible heritage (language, music, cultural expressions). This type of polyphony in music then became a symbol of identification, an element that affirmed the island's cultural existence, influenced by the political situation in the region which led in the existence of militants culturels. This in turn spawned an extended family of groups, beginning with Canta u Populu Corsu, whose aim was to defend and promote Corsican language and culture by means of song (Gattaceca, 1984), the songs in question being both traditional and of their own creation, and always in the Corsican language. In the late 1970s and early 1980s, attempts to organise musical evenings or concerts in the villages were increasingly met with hostility, not only by the French authorities and their local representatives, who viewed such activities as revolutionary and responded accordingly, but also by some of the islanders themselves, who found the traditional styles of singing and their association with a rural, backwards-looking way of life embarrassing and shameful, as well as being alienated by the associated political rhetoric (Bithell, 1996:40).

The interpretation of culture at that time pervaded all aspects of life, framed societal perceptions (Hofstede, 2001) and had an impact on people's behavior (Gentina et al., 2014). Eventually, the fact that Riaquistu movement considered polyphony, as something very static and serious and as the only cultural expression that could represent the island's character, was an obstacle for any other form of cultural activity including dance. This cultural movement took very fast a political dimension, living behind its initial purpose. Cultural identity and polyphonic singing, was then perceived as a flag of the island's nationalism.

However culture should be a lot more than something static, and something that would be the flag of apolitical movement. The model introduced by Geert Hofstede and Gert Jan Hofstede (2005) contributes to the understanding that culture and cultural differences can be described as: values, rituals, symbols and heroes which influence our practice. Dance expression is a cultural practice, which represents the collective habits that are visibly expressed and are influenced by deeper elements, such as values that are profoundly written in our mental programs. When dance becomes a part of a culture's values, by the usual practice and discussion, it is difficult to exclude it from the everyday practice. Many associations and music groups emerged at the time, with the aim to challenge this type of "original" identity that promoted the static polyphony as the only thing that created the cultural identity of the island.

\section{Dance associations}

A community that does not dance is a community that does not communicate, at least not as well as it should: "More than any other artistic popular language, dance expresses the variety of cultures, but also the exchange between individuals and communities, men and women, young and elder people... Dance is not just a spectacle to look at; it is an experience to live, no matter what is your age, your talent, the beauty of your body and the status of your society. A society that doesn't dance anymore is a close society ${ }^{4}$ " (Fanise 2006:6).

\footnotetext{
${ }^{4}$ The texts from French to English were translated by one of the authors.
} 
Another problem is depicted on the moment that a dance is no longer practiced, it starts to lose ground until it is finally forgotten. This is the reason that when usual ways of transmission are no longer in use, new ways should be invented. This is also the main purpose of this study. Indicate the importance of cultural protection and provide possible modes of communication to proceed towards concrete actions to achieve cultural preservation, development and promotion. Dance practice used to transmit orally from one generation to the other. Nevertheless, in a society that this procedure of transmission is no more in practice, it becomes very difficult to even find written or recorded traces that can prove the existence of popular dances. Dance associations in Corsica hold today this important role of transmission.

At the time of the study dance groups concerned mainly a particular age group in Corsica. More specifically, people from forty (40) to sixty (60) years old. For Alain Bitton-Andreotti, the man who created the federation of Corsican dances Tutti in Piazza and P.-P. Grimaldi, founding member of the dance association Ochju à Ochju,the more difficult thing for dance associations is to give people the will to dance.

\section{Intangible heritage and cultural identity}

Intangible heritage includes customs and oral traditions, music, languages, poetry, dance, festivities, religious ceremonies as well as systems of healing, traditional knowledge systems and skills connected with the material aspects of culture, such as tools and the habitat (Bouchenaki, 2003). Intangible cultural heritage uses, representations, expressions, knowledge and techniques - together with the instruments, objects, artefacts and the cultural spaces that are inherent to them - that communities, groups and, in some cases, even individuals are recognized as an integral part of the cultural heritage. Intangible cultural heritage is transmitted from generation to generation; it is constantly being created by communities and groups in the function of their surroundings, and in their interactions with culture and their history, and infuses them with a sense of identity and continuity, thus promoting respect for cultural diversity and the creativity of humankind (Ruiz-Chiriboga, 2006:45).

As culture is learned, shared and acquired by people through family, school and other social institutions, cultural heritage becomes automatically part of their cultural identity. At the same time, cultural identity is maintained through the efforts of its people via different practices. Cultural identity itself has been conceptualized as the entirety of the cultural references by which a person or a group can be defined, manifested, and wishes to be known; it implies liberties that are inherent to individual dignity in a permanent way, and integrates cultural diversity, both individually and universally, in memory and in plan (Draft Declaration on Cultural Rights 1998). Cultural heritage is an integral part of cultural identity, and must be understood as everything that forms part of a person's characteristic identity, and which, if desired, can be shared with other peoples (Daes, 1993).

Cultural preservation of dance in Corsica is vital for the maintenance of cultural identity, tradition and history of inhabitants. Considering that globalization has contributed to the homogenization of societies and to the potential disappearance and loss of cultural heritage, it is likely that cultural preservation is in danger. Globalization has been associated with the destruction of cultural identities, victims of the accelerating encroachment of a homogenized, westernized, consumer culture (Tomlinson, 2011:269). Safeguarding a culture does not denote solely maintenance of national and cultural identity, but also defence and preservation of cultural diversity. When societies are becoming more diverse in terms of immigration, religion, gender roles and traditions, it is important to preserve cultural heritage for keeping alive each 
culture in a world which constant changes due to the influence, interaction and possible clash of different values, beliefs and lifestyles among different cultures. That's why it becomes more vital to be able to coexist in diverse societies where there are harmonic relationships and mutual respect despite cultural differences.

\section{Ethnography and participant observation as a methodological approach}

Communication exists in all the actions that construct a society and its culture. We are talking of a social phenomenon, coextensive to culture, as every action of transmission depends on communication. People from a specific culture participate in social communication, as the members from the same orchestra (Winkin, 1998:114). The observer of this orchestra becomes a part of it. It is not by chance that anthropologists consider participant observation as the only way to study the act of communication. This study is situated within the borders of contemporary anthropology, where communication is not defined by its objects but by how it deals with them, by the objects it deals with, by how it communicates with social actors, and finally by how it expresses these experiences in public (Winkin, 1998). Ethnographic research is associated with the anthropology of communication and is based on three competences: know how to observe, know how to live with others, and know how to transfer all these experiences on a piece of paper (Winkin, 1998:113-114).

This research is based on the field study of observation where the researcher lived and experienced, during five (5) years (2003 to 2007), the cultural environment of this study, the researcher became the observer and the observed at the same time. She was actively participating at Corsican dance ateliers. She became part of this culture and its intangible heritage as a member. She was watching and recording their moves, their activities, their comments, their interaction and she had the opportunity even to participate and interact with three or four different groups of dance. The way people move, dress, interact and use space is very much a part of how particular social settings are constructed. Observation is the key method for collecting data about such matters (Muhall, 2002:307).

To explore the role of Corsica's dance associations, in the process of dance communication and cultural preservation, the approach of this research was mainly iterative and exploratory, to allow the researcher to be open to new information (Bernard, 1995; Jacob, 2009). Participant observation was an important exploratory data collection tool for this study. The task [of ethnographers] is to document the culture, the perspectives and practices, of the people in these settings. The aim is to 'get inside' the way each group of people sees the world (Hammersley, 1992). One of the main advantages that ethnographic research offers is the social interaction element that is created between the researcher and the participants. The researcher has the opportunity to achieve a deeper understanding of the motivations for certain social acts of the participants. Additionally the researcher can make out how the participants actions are depicted within society and consequently within the social and cultural organizations that they are member of or represent, as such of dance associations. This type of research allowed an exploration as to which certain tasks or roles, dance associations, are supposed to perform within society from a socio-cultural perspective, and what kind of relationship or relationships are developed between the two. 


\section{Sampling: Dance associations, activities and structure}

The associations which participated in the study were mostly situated in Corsica (94.11\%). Only one association maintained habitual dance activity both in Corsica and in continental France (Paris). Associative projects concerned research, promotion, transmission and diffusion of the island's cultural patrimony (dance and music). Most of the associations' members (33\%) learned how to dance in an associative environment. There was no annual calendar or agenda for dancing events. All the associations had a place to rehearse and practice.

The associations communicated their events with the use of the media and new media (radio, newspapers, magazines and the Internet). They did not target a particular public, although they would like all to include younger ages in their dance seminars. All the associations claimed to have difficulty to find the necessary resources in order to promote their actions. Finally, most of the associations (23\%), believe that wearing a costume is not necessary for their representations in public.

The biggest communication challenge, among the different associations, seems to be the diversity of the dance figures they use. Almost all the associations maintain different tactics concerning the way that a dance figure is practiced.

\section{Semi-structured interviews}

For the purposes of this study apart from participant observation, seventeen (17) semi-structured, openended interviews were conducted with key-members of the seventeen (17) more active dance associations. These associations where chosen based on the frequency of the dance seminars they organised. More particularly each of these associations had to organise at least one dance seminar per week. These associations are namely: Estudiantina Aiaccina, Sirinata Aiaccina, A Mannella, A Cirnea, A Paghjella, Cantu di cirnu, A Riesciuta, I Macchjaghjoli, A Squatriglia, Ochju à Ochju, Tutti in piazza, Quatrigliu in Aiacciu, A Piazzetta, A Liscinosa, Ballettu Strintu, Musical and A Casarella. The questions addressed to the associations were first of all sent by e-mail. More than one telephone discussions followed. Then face to face interviews took place, in order to examine in depth and triangulate some of the participants' answers. All the interviews were conducted in French, with the exception of some words (dance figures and expressions), which were expressed and transferred in the local Corsican dialect.

The interviews took the form of an open dialogue, between the researcher and the informants, as close to a normal conversation as possible (Bernard, 1995). In the course of the interview, questions included data about Corsican dances (dance figures and movements), actual activities and actions of the associations (seminars, dance courses), and future possible activities to promote dance events. Questions addressed to the dance associations were mainly organized in three parts: membership, technical elements (dance figures), function and functionalities.

One of the main purposes of the interviews was to invite participants and key actors of dance seminars, to give concrete examples, describing specific situations that in their opinion had affected their participation in dance events, especially with regard to other members and other associations. Anthropology of communication research needs concrete examples to be developed, as we speak of an ethnographical approach that deals with live places, real situations and personal experiences, and examines the way that 
culture is accomplished in everyday life (Winkin, 1998:116). Semi-structured interviews served as an opportunity to triangulate the data from those of participant observations.

A second sample study followed, this one concerned the views of young members of the community about their oral inheritance, age group between 17 to 26 years old. More specifically, fifteen students in Corsican languages and culture of 'Pascal Paoli' university were interviewed about their dance activity.

\section{Discussion of results}

In regards to the students' interviews in this particular discipline, it was expected that they would be more familiarized with their own culture and this is why they were chosen. Nevertheless, results showed that only a $10 \%$ from the student sample knew that a dance culture exists in the island that is familiar with the popular dance of Corsica, named quadrille. Surprisingly, none of the students knew how this dance was danced. Nevertheless, the positive element of this is that, most of the students $(90 \%)$ would like to learn how popular dances are practiced. The students explained that tradition for them was a very important part of their culture and that they shouldn't let it disappear. They also explained that in their own opinion there were not a lot of events that promoted popular dance, and that they had not yet been invited to participate in such an event.

\section{The experience of a Greek dance atelier - A connection}

The fact that this research refers to the importance of intangible cultural heritage and cultural preservation, makes it important to share the personal experience of one of the authors. For the purposes of this research a Greek dance atelier was initiated for a period of ten months (September to June). The main purpose of such an initiative was to identify feelings and possible reasons as to why the younger generation felt reluctant to be part of the dance culture. In this atelier some steps of the most well-known Greek dances were taught such as: Kalamatiano, Sirto and Hasapiko.The thoughts of a twenty-two (22) year old male student, originated from Corsica that participated in one of these dance courses can demonstrate how uncomfortable young people in Corsica feel with their 'exposure' to other people while dancing: "I would like to participate in the Greek dance course as long as my friends and family are not aware of it. Additionally, I would not in any way want to dance in public". The main conclusion that can be drawn from the above statement and the observation of other young people reactions, is that their non-participation in dance events is mostly due to their shyness and reluctance to express themselves in public. Younger people in Corsica seem that they do not have the habit to express emotions via dance, as this is not part of their usual habits (cultural expression), like in Greece for example, where it is common to express emotions (joy and pain) via dance.

\section{The benefit of intergroup contact}

As it has been suggested in this study so far, the lack of communication which exists among the different dance groups in Corsica is a major issue. To be more specific, each group follows different dance rules and figures, which makes the dance transmission challenging and consequently its preservation. The issues which arise focus not only on ways of transmission but also on what to transmit. For Jacques Thiers (1989:144), the inhabitants should accept the fact that we live in an era of sharing and exchange and that it is impossible to keep something intact. Intergroup contact could help resolve the communication insufficiencies. According to the Intergroup Contact Theory, contact amongst groups that takes place under 
optimal conditions can improve intergroup attitudes. The conditions to promote favorable intergroup relations are: equal status amongst groups, common goals, co-operation, institutional support (Allport, 1954) and the projection of trait positivity (Stathi \& Crisp, 2010). Speaking of the last condition (the projection of trait positivity), positive contact evokes greater self-outgroup similarity, which increases outgroup liking via the projection of positivity. Both the projection of positivity and reduced anxiety, but independently from one another, results in improved out-group attitudes.

Positive impact of cultural communication are sharing and exchanging. Cultural advantages are always accompanied by economic and social benefits. Direct and indirect contact share similar social location and personal predictors (Pettigrew et al., 2007). Indirect contact has also positive consequences not only for the participants but also for the non-participants, whose friends and associates experience contact.

Intergroup contact is a necessary but insufficient condition, by itself, to resolve intergroup conflict (Pettigrew 2008). Based on the assumption that ignorance promotes prejudice (Stephan \& Stephan, 1984), Pettigrew (1998) proposed that 'learning about others' is a critical step in how intergroup contact improves intergroup relations. Even if lacking interaction among dance groups is not the only insufficiency related to the communication problem of dance associations in Corsica, it represents an important cause for dance disregard. Researchers dealing with social categorization, emphasize that similar organization members interact more with each other than with non-similar individuals (Tsui et al. 1992). Nevertheless, most of the associations' members that we examined were mainly originated from the island. Turner (1987), argues that if group membership is unsatisfactory, members will attempt to leave that group. Even when that is not physically possible, individuals may engage themselves in other forms of reduced attachment, such as psychologically withdrawing from the community (Turner, 1987).

To avoid such situations, a global working environment needs to be created. The aim is to mix individuals from different cultures with different knowledge and perspectives, and let them communicate, share and exchange. This is possible during the annual dance festivals that are organised on the island. At the time, people from all over the world, with different nationalities and cultures, participate in summer dance courses and festivities. By creating teams with criteria such as nationality and avoid groupings based on cultural and linguistic affiliation, it can nurture possible narrow minded or ethnocentric viewpoints.

\section{The benefit of Cultural Education}

The contribution of cultural education can be invaluable in such a step towards the support of a global networking environment, so as to prepare young adults towards the appreciation of such cultural activities. Already, this research has shown that young generation in Corsica is not familiar with its islands dance culture. Cultural education, in the form of knowledge transfer, can introduce young people and adults the essence and importance of culture, and of certain cultural activities such as dance. We believe that a sociocultural intervention incorporating dance education in the official educational curriculum of Corsica, can enhance the cultural awareness of Corsicans at an early age by connecting dance education with culture and contributing to the better understanding and appreciation of their cultural heritage. Johnson (1992) supports that our bodies and bodily experiences are shaped by history and culture. He sees the body as a viewpoint and claims: "My body-its sensibilities, movements styles, reaction patterns, and health - is not 
Special Issue 1, December 2019, Journal of Education, Innovation, and Communication (JEICOM), pages: 53-66 DOI : https://doi.org/10.34097/jeicom_SI_Dec2019-4

simply an individual reality governed by its own biophysical laws and idiosyncratic effects on my personal history. I am also a result of the ideologies within which I move”. A bodily and dance experience are products which are generated within society. Culture and society are two systems which coexist, they are not viewed separately, but they influence and develop each other. As it has been already discussed in this paper, culture is learned, shared and acquired through social systems, with education being one of them.

One of the main aims of education in general is to create responsible individuals who are characterized by competencies, attitudes and mind-set that help them to appreciate and respect cultural differences and diversity, by engaging and interacting successfully with people from different cultural groups. A global networking environment supported by cultural education could result in the development of cultural empathy among members which is a fundamental trait in a globalized world and towards the development of harmonic intercultural relationships. Cultural empathy signifies understanding, respect and recognition of differences and similarities that exist among different cultures. It refers as to whether the individual can empathize with the feelings and behaviors of people from different cultures (Arabski \& Wojtaszek, 2011:51). The more exposure and interaction that one's develop with people from different cultural groups, higher his or her tolerance levels are. Thus, culture is viewed as not something prone, waiting to be discovered but an active meaning-making system of experiences which enters into and is constructed within every act of communication (Barro et al., 1998:83). Then, group members' identification could help Corsican dance promotion.

\section{The benefit of identification promotion}

Identification implies a feeling of being part of the group (Tajfel \& Turner, 1979). High levels of identification with the organization might occur, despite low perceived similarity in cultural values, when the intercultural group climate remains strong (Luijters, 2008). The important for the dance association members' identification is that from the moment that members identify themselves with the association, they will also put effort in the achievement of its organizational goals: "Organizational identification aligns individual interests and behaviors with interest and behaviors that benefit the organization. This means exertion on behalf of the organization is also exertion on behalf of the self' (Dutton et al., 1994:256). At the same time, perceived similarity in values is lower when many different cultural identities are present (Luijters et al., 2008; Hofstede, 1999; Schwartz, 2002).

The role of perceived similarity and an intercultural group climate, as far as identification promotion is concerned, is examined in the research of Kyra Luijters et al. (2008). Different studies were conducted in a public place known for its diverse population (the Netherlands, Amsterdam central station) and in a large Dutch employment agency's employee. Results showed that perceived similarity in cultural values is positively related to identification with the team and the organization and that the negative effect of low perceived similarity in values on identification with the organization can be buffered by an intercultural group climate. Differently said, despite low perceived similarity in values, identification levels can be equally high as a result of a strong intercultural group climate. The above statement can offer a clear guideline for the situation of dance associations in Corsica: in order to enhance identification within a diverse organization, an intercultural group climate, in which diversity is perceived as a positive feature, should be developed. This is how a common direction that would permit a common program with common 
dance figures and functionality, could be achieved. Then, the associations' communication problem(s) could reduce and even disappear.

Additionally, according to Social Identity Theory (Tajfel \& Turner, 1979) and Self-Categorization Theory (Turner et al., 1987), people particularly identify themselves with a group when they perceive to have similar characteristics as their fellow group members. This is the case of dance associations' members in Corsica. Dance associations are mainly created by homogenous groups that perceive similarity in cultural background. However, culturally diverse group members do not perceive this similarity, fact that creates lower identification than with culturally homogenous groups (Chattopadhyay Tluchowska \& George, 2004; O’Reilly et al., 1989; Tsui Egan \& O’Reilly, 1992).

It is also important to mention how mutual respect can help the communication process of a group. Mutual respect can give positive results on identification, as it can contribute to better intergroup relations (Luijters2008; Barreto \& Ellemers, 2002; Huo \& Molina, 2006; O’Brien et al., 2005). From the moment that association members learn how to interact with one another, they can easily reconcile their values. This is how they can learn to respect one another, find common purposes, identify themselves with the group and finally improve their internal and external communication. This process is much more likely to occur on a team level, where people frequently interact and have the opportunity to discuss their values, than on a more abstract organizational level (Campion et al., 1993; Anderson \& West, 1998).

\section{The benefit of following a common tactic}

As far as dance figures rules are concerned, our research showed that if a common route is agreed and followed by all the associations, a common tactic concerning figures rules can be accepted as well. In this way, all the associations could work in a common project that would help dance practice and promotion. Additionally, the encouragement of dance creation, the announcement of events dates with the help of a detailed calendar, the proposal of dance contests and the creation of adequate structures for dance events, would help dance transmission and promotion. The moment of the research only three adequate places for the organization of dance spectacles seemed to be active, namely Aghja in Ajaccio (70 places), the municipal theatre of Bastia ( 850 places) and the Propriano theatre (400 places).

Wanting to examine the actual situation of dance practice in Corsica some years after this study, we contacted (12/12/2019) Bernard Pazzoni, responsible of the Corsican museum music archives library. He explained that unfortunately dance patrimony is almost a lost practice. Dance associations have stopped their practice, apart from very rare occasions ${ }^{5}$.

\footnotetext{
${ }^{5}$ « Eh bien les associations de danses comme le quadrille se sont essoufflées. Et dans les villages il n'y a plus d'anciens pour participer. Les mariages sont complètement américains avec DJ. Il'n y a que quelques apparitions, comme les danseurs (originaires du Continent) de la région de PortiVecchju, l'autre soir qui ont dansé les 2 Muresche .... à la Festa di a Nazione à CONCA .... bref la Corse devient bientôt les DOM TOM , La GUYANNE etc.... ». Bernard Pazzoni, interview, 12/12/19.
} 


\section{Conclusion}

This study contributes scientifically to cultural studies in action, proposing ways to accomplish better interaction among cultural practitioners and associations, with a goal to improve intergroup relations and help with dance promotion. It has been examined that an oral patrimony in risk of disappearance has the choice to innovate, promote, adapt and avoid a cultural loss. The purpose was first of all to understand in what ways an oral patrimony can be affected by social changes and globalisation, suggest actions to avoid a possible cultural loss and promote intercultural communication.

Losing the memory of our past is like forgetting all the elements that create our own personality (Salini, 2004:12). Nevertheless, when a cultural activity is no longer practiced, it will soon or later disappear. Dance activity in Corsica, was at the time of the study, considered, by many people, especially the younger ones, an unknown practice.

The moment of the research, dance associations in Corsica were the only places where popular dances were practiced. This field study research showed that there is a problem of communication among dance associations. Mutual respect and better understanding of the situation could help the associations propose and follow a common project to ameliorate the actual situation. Follow common rules, propose a specific agenda with dance events, invite younger people to dance, achieve members' identification by creating intercultural groups, mixing the teams with regard to nationality, promote cultural education and research, follow a common tactic of dance figures, are some of the actions that could help dance activity's transmission and promotion. Furthermore, better communication among the different dance groups in Corsica, the cultural actors and the society, would contribute to the protection of this oral patrimony in risk of disappearance.

Culture includes collective practices, like the celebrations and the models of social interaction. Its comprehension by different members of the community is very crucial (Warnier, 1999:9). People from different cultures could eventually communicate successfully and learn to respect one another by being sensitive to cultural diversity, avoid stereotyping and prejudice and learn how to negotiate communication barriers. Cultural practices, like dancing, could provide a solution to a society's miscommunication.

Suggestions for future research could examine to a greater extent the mediating and moderating role of group processes and power relations linked to oral patrimonies, as well as the economic and generally the social benefits that are related to dance promotion and transmission. 


\section{References}

Allport, G. W. (1954). The nature of prejudice. Garden City, NY: Doubleday.

Alvesson, M. (2003). Beyond neopositivists, romantics, and localists: A reflexive approach to interviews in organizational research. Academy of Management Review, 28(1), 13-33.

Anderson, N. R., \& West, M. A. (1998). Measuring climate for work group innovation: Development and validation of the team climate inventory'. Journal of Organizational Behavior, 19(3), 235-258.

Apte, M. (1994). Language in sociocultural context. In: R. E. Asher (Eds.), The Encyclopedia of Language and Linguistics. Vol.4 (pp. 2000-2010). Oxford: Pergamon Press.

Arabski, J. \& Wojtaszek, A. (2011). Aspects of culture in second language acquisition and foreign language learning. Berlin: Springer.

Bekemans, L. (2013). Educational challenges and perspectives in multiculturalism vs. interculturalism: citizenship education for intercultural realities. In M. Barrett (Eds.), Interculturalism and multiculturalism: similarities and differences (pp. 169-187). Council of Europe: Strasbourg.

Barreto, M., \&Ellemers, N. (2002). The impact of respect versus neglect of self-identities on identification and group loyalty. Personality and Social Psychology Bulletin, 28(5), 629-639.

Barro, A., Jordan, S., \& Roberts, C. (1998). Cultural practice in everyday life: the language learner as ethnographer. In M. Byram\& M. Flemings (Eds.), Language Learning in Intercultural Perspective: Approaches through Drama and Ethnography (pp. 76-97). Cambridge, UK/New York: Cambridge University Press.

Bernard, R. H. (1995). Research methods in anthropology: Qualitative and quantitative approaches. Thousand Oaks: Sage.

Bithell. C. (1996). Polyphonic voices: National identity, world music and the recording of traditional music in Corsica. British Journal of Ethnomusicology, 5(1), 39-66.

Bouchenaki, M. (2003). The interdependency of the tangible and intangible cultural heritage. Paper presented at the, ICOMOS 14th General Assembly and Scientific Symposium.

Campion, M. A., Medsker, G. J., \& Higgs, A. C. (1993). Relations between work group characteristics and effectiveness: Implications for designing effective work groups. Personnel Psychology, 46,(4), 823850.

Carte de France, 2019. Region Corse. [online] Available at: http://www.map-france.com/region-Corse/ [Accessed 15 April 2019]

Chattopadhyay, P., Tluchowska, M., \& George, E. (2004). Identifying the ingroup: A closer look at the influence of demographic dissimilarity on employee social identity. Academy of Management Review, 29(2), 180-202.

Curtin, P., \& Gaither, T. K. (2005). Privileging identity, difference and power: The circuit of culture as a basis for public relations theory. Journal of Public Relations Research, 17(2), 91-115.

Davis, S. (2011). The Corsican quest for the real: The struggle for self-identification among cultural militants in Corsica's movement for cultural reacquisition. PhD Dissertation. Ebory University.

Draft Declaration on Cultural Rights (1998). Article 1.

Dutton, J. E., Dukerich, J. M., \&Harquail, C. V. (1994). Organizational images and member identification. Administrative Science Quarterly, 39(2), 239-263.

Edwards, L. (2005). Rethinking power in public relations. Public Relations Review, 32(3), 229-231.

Fanise, P. (2006). Danse avec le monde! Accordance, Avril-Juin, ${ }^{\circ} 37$.

Gattaceca, P. (1984). La production discographique corse de 1973 a 1983. DEA thesis, University of Corte. 
Special Issue 1, December 2019, Journal of Education, Innovation, and Communication (JEICOM), pages: 53-66 DOI : https://doi.org/10.34097/jeicom_SI_Dec2019-4

Gentina, E., Butori, R., Rose, G. M., \&Bakir, A. (2014). How national culture impacts teenage shopping behavior: Comparing French and American consumers. Journal of Business Research, 67(4), 464-470.

Hammersley, M. (1992). What's wrong with ethnography? Methodological explorations. London: Routledge.

Hofstede, G. (1999). Allemaalandersdenkenden. Omgaan met cultuurverschillen Amsterdam: Uitgeverij Contact. pp. 18-21.

Hofstede, G. (2001). Culture's consequences: Comparing values, behaviors, institutions, and organizations across nations. 2nd ed. Thousand Oaks: Sage.

Hofstede, G., \&Hofstede, G. J. (2005). Cultures and organizations: Software of the mind. 2nd ed. New York: Mcgraw-Hill.

Huntington, S. P. (2000). Le choc des civilisations. Paris: Odile Jacob.

Huo, Y. J., \& Molina, L. E. (2006). Is pluralism a viable model of diversity? The benefits and limits of subgroup respect. Group Processes and Intergroup Relations, 9(3), 359-376.

Jenkins, R. (1996). Social identity. London: Routledge.

Johnson, D. (1992). Body: Recovering our sensual wisdom. Berkeley, CA: North Atlantic Books and Somatic Resources.

Kefalaki M. (2010), L'identité Culturelle en Méditerranée : musiques et danses de Corse et de Naxos, éditions universitaires européennes, USA. (ISBN: 978-613-1-55355-4).

Luijters, K., Zee, I. \& K. Otten, S. (2008). Cultural diversity in organizations: Enhancing identification by valuing differences. International Journal of Intercultural Relations, 32(2), 154-163.

Mulhall, A. 2003. In the field notes on observation in qualitative research. Journal of Advanced Nursing, 41(3), pp. 306-313.

O’Brien, A., Haslam, A., Jetten, J., \& O’Sullivan, L. (2005). Building sustainable diversity. The role of intergroup respect. Paper presented at the 14th General Meeting of the European Association of Experimental Social Psychology, Wurzburg, Germany.

O'Reilly, C. A., Caldwell, D. F., \& Barnett, W. P. (1989). Work group demography, social integration, and turnover. Administrative Science Quarterly, 34(1), 21-37.

Pettigrew, T. F., Oliver, C., Wagner, U., Stellmacherb, J. (2007). Direct and indirect intergroup contact effects on prejudice: A normative interpretation. International Journal of Intercultural Relations, 31(4), 411-425.

Pettigrew, T. F. (2008). Future directions for intergroup contact theory and research. International Journal of Intercultural Relations, 32(3), 187-199.

Pettigrew, T. F. (1998). Intergroup Contact Theory. Annual Review of Psychology, 49(1), 65-85.

Ruiz-Chiriboga, O. (2006). The right to cultural identity of indigenous peoples and national minorities: A look from the Inter-American System. International Journal of Human Rights, 3(5), 42-69.

Salini, D. (2004). La Corse dans sa dimension anthropologique. EncyclopaediaCorsicae, II. Corse: Dumane.

Schwartz, S. H. (2002). Relations of culture to social structure, demography and policy in the study of nations. Invited Lecture at the 25th International Congress of Applied Psychology, Singapore.

Spencer-Oatey, H. (2008). Culturally speaking. Culture, communication and politeness theory. 2nd ed. London: Continuum.

Stathi S., \& Crisp R. J. (2010). Intergroup contact and the projection of positivity. International Journal of Intercultural Relations, 34 (6), 580-591. 
Stephan, W. G., \& Stephan, C. W. (1984). The role of ignorance in intergroup relations. In N. Miller \& M. B. Brewer (Eds.), Groups in Contact: The Psychology of Desegregation (pp. 229-257). Orlando, FL: Academic Press.

Tajfel, H., \& Turner, J. C. (1979). An integrative theory of intergroup conflict. In W. C. Austin \& S. Worchel (Eds.), The Social Psychology of Intergroup Relations (pp.33-47). Monterey, CA: Brooks/Cole.

Thiers, J. (1979). Aspects de la francisation au XIXème siècle en Corse. In Etudes Corses, $\mathrm{n}^{\circ}$ 9, Aiacciu, pp. $5-40$.

Thiers, J. (1989). Papiers d'identité(s). Genova: Albiana.

Tomlinson, J. (2003). Globalization and cultural identity. In D. Held (Eds.), The Global Transformations Reader: An Introduction to the Globalization Debate (pp. 269-277). Cambridge, UK: Polity.

Tsui, A. S., Egan, T. D., \& O'Reilly, C. A. (1992). Being different: Relational demography and organizational attachment. Administrative Science Quarterly, 37(4), 549-579.

Turner, J. C., Hogg, M. A., Oakes, P. J., Reicher, S. D., \& Wetherell, M. S. (1987). Rediscovering the social group: A Self-Categorization Theory'. Oxford: Basis Blackwell.

Warnier, J.P. (1999). La Mondialisation de la culture. Paris : La Découverte.

Winkin, Y. (1998). Vers une anthropologie de la communication ? In Philippe Cabin (coordonné par), La Communication, Etat des Savoirs (pp. 111-117). 